\title{
STATISTICAL OBSERVATION ON ANGIOMA SENILE
}

\author{
MASAKATSU IZAKI and YUTAKA KIMURA \\ Department of Dermatology, School of Medicine, \\ Keia University
}

(Received on February 10, 1955)

Concerning this dermatosis, which is commonly seen in middle-aged people, there is a precise description by Jadassohn (1909). Recently, in 1947, statistical observation in this condition was reported by Murison et al.

The existence of this skin disorder was first noted by Campbell De Morgan in his book "On the Origin of Cancer" (1872), and since then it has been known widely as De Morgan's spots. However, it is said that, at that time, De Morgan believed these spots to indicate or presage malignant disease, particularly of the stomach. In 1902, Raff reported this condition as angioma senile. Thereafter, it has been described as Kapillarvaricen, papillary varices, cayenne pepper spots, points rubris, etc., and has been paid attention as to be one of the so-called senile changes of the skin.

In this paper this dermatosis was observed statistically in Japanese. individuals.

\section{STATISTICAL OBSERVATION}

The observations here presented were made along with the statistical study on angiokeratoma of the scrotum (Fordyce), and a part of this observation has been already published in Japanese. (Ref. Studies on Senile Changes in the Skin I. Statistical Observation: Journal of the Keio Medical Society Vol. 28, No. 2, p. 59, 1951. Angiokeratoma of the Scrotum (Fordyce): Keio Journal of Medicine Vol. 1, No. 1, p. 61, 1952).

At the time this study was performed, it has been known that there were some confusions between angioma senile of the scrotum, which condition is stated by Jadassohn, Dohi, etc. to exist, and angiokeratoma of the scrotum (Fordyce). However, Wile-Belote, Weidman, Ormsby, Montgomery and Robinson-Tasker strongly stated that no essential histologic difference exists between both these dermatosis, and that angiokeratoma of the scrotum should be classified as an atypical case of angioma senile. Therefore, we first decided not to include the scrotum as the occurrence site of angioma senile, and so the ruby spots observed 
in the scrotum were all excluded from the statistical studies of angioma senile, and were studied separately statistically and histopathologically giving the result that ruby spots of the scrotum appears to be entirely histologically angiokeratomas and are due largely to age and should be differentiated from either angiokeratoma Mibelli or angioma senile.

The area of skin examined for spots was from head to toe and especially precise examination on the trunk. Observations were made on 585 patients over 31 years old at Keio Hospital, Okura National Hospital and aged people at Yokohama Dai-ichi Hogo Ryo. Further 1217 young men from 16 to 30 years of age, mostly applicants for Keio High School and Keio University's entrance examination were observed. Totals of persons examined were 1802 persons, of which 1552 were males and 250 females. Their ages varied from 16 to 84 years, divided into seven groups: that is, the late teen-agers (16-20), persons of the third decade (21-30), of the fourth decade (31-40), of the fifth decade (41-50), of the sixth decade (51-60), of the seventh decade (61-70) and a group of persons over 71 years of age.

Influence of Age on. Incidence

The number of persons and the incidence of angioma senile according to age in each age group are briefly summarized in table 1 . This condition is one of the skin changes which are due largely to age, significant difference being noticed among the incidences of the above mentioned groups. Its occurrence is already seen rather frequently in the late teen-agers, the incidence in this group being $\frac{14.09 \%}{17.45 \% \sim 1.43 \%}$ (Occurrence percentage/Confidence limit: Upper limit Lower limit). As ages advance its incidence gradually increase and it is especially noticed after 40 years of age, the incidence after 40 years being $\frac{68.91 \%}{73.63 \% \sim 66.49 \%}$ in male, and $70 \frac{64.43 \%}{70.02 \% \sim 59.56 \%}$ in female. However, mo signifcant difference was notable among the incidences of the fifth, sixth and seventh decade. Further, on the other hand, its frequency rather decreased after 71 years. of age.

\section{Sex Incidence}

While 1552 males were examined for this spot, only 250 females were observed for the same. However, the statistics which was handled by the small sampling method revealed that the frequency of patients with spots was almost the same in males and females, no significant difference being noticed between the incidence of the male and female (age for age, and also in whole). (Table 1) 
Table 1

Age and Sex Incidence of Angioma Senile

\begin{tabular}{|c|c|c|c|c|c|c|}
\hline \multirow{2}{*}{ Age } & \multirow{2}{*}{ Sex } & \multirow{2}{*}{$\begin{array}{l}\text { Number } \\
\text { of cases } \\
\text { examined }\end{array}$} & \multirow{2}{*}{$\begin{array}{l}\text { Positive } \\
\text { cases }\end{array}$} & \multirow{2}{*}{ Occurrence $\%$} & \multicolumn{2}{|c|}{ Confidence limit } \\
\hline & & & & & Upper limit \% & Lower limit \% \\
\hline $16-20$ & $\mathbf{M}$ & 887 & 125 & $14.09 \%$ & $17.45 \%$ & $11.43 \%$ \\
\hline $21-30$ & $\dot{\mathbf{M}}$ & 330 & 75 & 22.73 & -28.15 & 17.81 \\
\hline $31-40$ & $\begin{array}{l}\mathbf{M} \\
\mathbf{F}\end{array}$ & $\begin{array}{l}97 \\
56\end{array}$ & $\begin{array}{l}54 \\
25\end{array}$ & $\begin{array}{l}55.67 \\
44.64\end{array}$ & $\begin{array}{l}66.67 \\
60.18\end{array}$ & $\begin{array}{l}44.01 \\
30.29\end{array}$ \\
\hline $41-50$ & $\begin{array}{l}\mathrm{M} \\
\mathrm{F}\end{array}$ & $\begin{array}{l}84 \\
57\end{array}$ & $\begin{array}{l}59 \\
43\end{array}$ & $\begin{array}{l}70.24 \\
75.44\end{array}$ & $\begin{array}{l}80.42 \\
86.20\end{array}$ & $\begin{array}{l}57.87 \\
60.82\end{array}$ \\
\hline $51-60$ & $\begin{array}{l}\mathrm{M} \\
\mathrm{F}\end{array}$ & $\begin{array}{l}67 \\
59\end{array}$ & $\begin{array}{l}50 \\
40\end{array}$ & $\begin{array}{l}74.63 \\
67.80\end{array}$ & $\begin{array}{l}85.00 \\
80.15\end{array}$ & $\begin{array}{l}61.28 \\
52.70\end{array}$ \\
\hline $61-70$ & $\begin{array}{c}\mathrm{M} \\
\mathrm{F}\end{array}$ & $\begin{array}{l}63 \\
42\end{array}$ & $\begin{array}{l}43 \\
24\end{array}$ & $\begin{array}{l}68.25 \\
57.14\end{array}$ & $\begin{array}{l}79.75 \\
72.76\end{array}$ & $\begin{array}{l}53.24 \\
40.41\end{array}$ \\
\hline $71 \rightarrow$ & $\begin{array}{c}\text { M } \\
\text { F }\end{array}$ & $\begin{array}{l}24 \\
36\end{array}$ & $\begin{array}{l}12 \\
19\end{array}$ & $\begin{array}{l}50.0 \\
52.78\end{array}$ & $\begin{array}{l}71.43 \\
70.68\end{array}$ & $\begin{array}{l}28.57 \\
33.97\end{array}$ \\
\hline Totals & $\begin{array}{l}\text { M } \\
\text { F }\end{array}$ & $\begin{array}{c}1552 \\
(335) \\
250\end{array}$ & $\begin{array}{c}418 \\
(218) \\
151\end{array}$ & $\begin{array}{c}26.93 \\
(65.07) \\
60.4\end{array}$ & $\begin{array}{c}29.80 \\
(71.34) \\
67.40\end{array}$ & $\begin{array}{c}24.96 \\
(58.64) \\
52.78\end{array}$ \\
\hline
\end{tabular}

N.B. Totals male 1522 - totals in male after 16 years.

- 335- totals in male after 31. years.

\section{Distribution}

In order to find out the part of the body in which this dermatosis is most frequently noticed, the occurrence site of the ruby spots in each positive case was counted and briefly summarized in table 2 . It goes without saying that each site was counted even in cases in which the spots were noticed in one or more sites. It is revealed statistic significantly that these ruby spots are most frequently observed on the breast, next the back. The abdomen takes the third place. Also it is occasionally seen on the upper arm and the thigh. It may also appear on the nape and neck, face, head. However, it is rarely noticed on the leg and lips. In adolescence it is mostly seen on the breast and the back, and as ages advance it is likely to appear on the abdomen.

\section{Increase in Number of Ruby Spots with Age}

In an attempt to see how they increase in number, the number of spots in each case was investigated, and statistical observation was 'made dividing the positive cases in three groups according to the number of spots noticed: group 1 is consisted of patients having but one spot, group 2 of patients 
Table 2

Distribution of Angioma Senile

\begin{tabular}{|c|c|c|c|c|c|c|c|c|c|c|c|c|}
\hline \multirow[b]{2}{*}{ Age } & \multirow[b]{2}{*}{ Sex } & \multicolumn{11}{|c|}{ Occurrence site / Positive Cases \% } \\
\hline & & Face & Head & $\begin{array}{c}\text { Nape } \\
\& \\
\text { Neck }\end{array}$ & Breast & Back & $\begin{array}{c}\text { Abdo- } \\
\text { men }\end{array}$ & $\begin{array}{c}\text { Upper } \\
\text { Arm }\end{array}$ & $\begin{array}{c}\text { Fore- } \\
\text { arm }\end{array}$ & Thigh & Leg & Lips \\
\hline $16-20$ & $\mathbf{M}$ & $0.8 \%$ & & $2.4 \%$ & $64.8 \%$ & $58.4 \%$ & $7.2 \%$ & $2.4 \%$ & & $0.8 \%$ & & \\
\hline $21-30$ & $\mathbf{M}$ & 1.3 & & 10.4 & 70.2 & 44.2 & 9.1 & 11.7 & & 3.9 & & \\
\hline $31-40$ & $\begin{array}{l}M \\
F\end{array}$ & $\begin{array}{l}5.7 \\
4.0\end{array}$ & $7.6 \%$ & $\begin{array}{l}11.4 \\
16.0\end{array}$ & $\begin{array}{l}77.9 \\
72.0\end{array}$ & $\begin{array}{l}83.6 \\
48.0\end{array}$ & $\begin{array}{l}30.4 \\
28.4\end{array}$ & $\begin{array}{l}22.8 \\
20.0\end{array}$ & $\begin{array}{l}1.9 \% \\
4.0\end{array}$ & \begin{tabular}{|l|}
11.4 \\
16.0
\end{tabular} & & $1.9 \%$ \\
\hline $41-50$ & $\begin{array}{l}\text { M } \\
\text { F }\end{array}$ & $\begin{array}{l}5.1 \\
6.9\end{array}$ & $\begin{array}{l}8.5 \\
2.3\end{array}$ & $\begin{array}{r}10.2 \\
9.2\end{array}$ & $\begin{array}{l}86.7 \\
85,1\end{array}$ & $\begin{array}{l}59.5 \\
62.1\end{array}$ & $\begin{array}{l}39.1 \\
23.0\end{array}$ & $\begin{array}{l}25.5 \\
18.4\end{array}$ & $\begin{array}{l}6.8 \\
4.6\end{array}$ & \begin{tabular}{|r|}
17.0 \\
6.9
\end{tabular} & $1.7 \%$ & 6.9 \\
\hline $51-60$ & $\begin{array}{l}\mathbf{M} \\
\mathbf{F}\end{array}$ & $\begin{array}{r}8.0 \\
10.0\end{array}$ & $\begin{array}{r}14.0 \\
2.5\end{array}$ & $\begin{array}{r}4.0 \\
12.5\end{array}$ & $\begin{array}{l}94.0 \\
95.0\end{array}$ & $\begin{array}{l}78.0 \\
67.5\end{array}$ & $\begin{array}{l}62.0 \\
55.0\end{array}$ & $\begin{array}{l}24.0 \\
20.0\end{array}$ & $\begin{array}{l}8.0 \\
5.0\end{array}$ & \begin{tabular}{|l|}
10.6 \\
22.5
\end{tabular} & & $\begin{array}{l}2.0 \\
2.5\end{array}$ \\
\hline $61-70$ & $\begin{array}{c}\text { M } \\
\text { F }\end{array}$ & $\begin{array}{r}13.8 \\
4.2\end{array}$ & 11.5 & $\begin{array}{r}4.6 \\
25.2\end{array}$ & $\begin{array}{l}85.1 \\
92.4\end{array}$ & $\begin{array}{l}64.4 \\
54.6\end{array}$ & $\begin{array}{l}55.2 \\
58.8\end{array}$ & $\begin{array}{l}18.4 \\
21.0\end{array}$ & $\begin{array}{r}6.9 \\
12.6\end{array}$ & $\mid \begin{array}{l}23.0 \\
210\end{array}$ & 2.3 & 2.3 \\
\hline $71 \rightarrow$ & $\begin{array}{c}\mathbf{M} \\
\mathbf{F}\end{array}$ & $\begin{array}{l}8.3 \\
5.3\end{array}$ & 16.6 & $\begin{array}{r}16.6 \\
5.3\end{array}$ & \begin{tabular}{|l|}
91.3 \\
74.2
\end{tabular} & $\begin{array}{l}41.5 \\
63.6\end{array}$ & $\begin{array}{l}58.1 \\
37.1\end{array}$ & $\begin{array}{r}8.3 \\
15.9\end{array}$ & $\begin{array}{r}8.3 \\
10.6\end{array}$ & 10.6 & & \\
\hline Totals & $\begin{array}{c}\mathrm{M} \\
\overline{\mathrm{F}}\end{array}$ & $\begin{array}{l}4.5 \\
6.6\end{array}$ & $\begin{array}{l}5.5 \\
1.3\end{array}$ & $\begin{array}{r}6.9 \\
13.2\end{array}$ & $\begin{array}{l}77.0 \\
85.4\end{array}$ & $\begin{array}{l}61.7 \\
60.3\end{array}$ & $\begin{array}{l}28.0 \\
39.7\end{array}$ & $\begin{array}{l}13.9 \\
19.2\end{array}$ & $\begin{array}{l}3.1 \\
6.6\end{array}$ & $\begin{array}{r}8.4 \\
15.2\end{array}$ & 0.5 & $\begin{array}{l}0.7 \\
2.6\end{array}$ \\
\hline
\end{tabular}

Table 3

Influence of Age on Number of Angioma Senile

\begin{tabular}{c|c|c|c|c}
\hline \multirow{2}{*}{ Age } & Sex & \multicolumn{3}{|c}{ Number of Ruby Spots } \\
\cline { 3 - 5 } & & 1 & $2-10$ & $11 \rightarrow$ \\
\hline $16-20$ & M & $64.8 \%$ & $35.2 \%$ & \\
\hline $21-30$ & M & 52.0 & 48.0 & \\
\hline \multirow{2}{*}{$31-40$} & M & 25.9 & 50.0 & $24.1 \%$ \\
& F & 24.0 & 72.0 & 4.0 \\
\hline \multirow{2}{*}{$41-50$} & M & 18.7 & 61.0 & 20.3 \\
& F & 25.6 & 60.5 & 13.9 \\
\hline \multirow{2}{*}{$51-60$} & M & 16.0 & 60.0 & 24.0 \\
& F & 10.0 & 67.5 & 22.5 \\
\hline \multirow{2}{*}{$61-70$} & M & 30.2 & 48.9 & 20.9 \\
& F & 12.5 & 54.2 & 33.3 \\
\hline \multirow{2}{*}{$71 \rightarrow$} & M & 33.3 & 50.0 & 16.7 \\
& F & 31.6 & 57.9 & 10.5 \\
\hline \multirow{2}{*}{ Totals } & M & 40.7 & 47.8 & 11.5 \\
& F & 19.9 & 62.9 & 17.2 \\
\hline
\end{tabular}

N.B. $\%=$ Number of Cases in Each Group/Positive Cases $\times 100$. 
having two to ten spots, and group 3 of patients having more than eleven. spots. The results are given in table 3 . In the late teen-agers the majority of the positive cases showed only one spot, however, as ages advance the number increases, after the fourth decade the majority showing two or more spots. But it is interesting to notice that still a good number of cases show only one spot in patients over sixty years of age.

\section{COMMENT}

Angioma senile, which skin disorder is characterized by its minute and ruby coloured features, has been statistically observed by Raff and recently by Murison et al. The occurrence incidence of this condition in the Japanese has been reported by Kodama (1942) and later by Kojima (1944).

Raff describes that this condition is relatively rare before thirty years of age, and thereafter frequently noticeable. After fourty years of age it is seen in about half of the individuals, and after sixty years it may appear in three fourth or more of the people. Murison et al reports that the proportion of patients with spots rises progressively with age at all events up to the age of 70. In adolescence some $5 \%$ of patients have spots, but thereafter the proportion increases throughout adult life to about $75 \%$ at 70 years of age.

In Japan, Kodama investigating this spots in 1264 persons reported that this disorder was noticed in about $3.2 \%$ of the people of the third decade, and as ages advance the proportion increased. In male the peak was noticed in the fifth decade, the incidence being $20 \%$, while in female the incidence gradually increased to about $33.3 \%$ at 70 years of age. Kojima observed this condition in 635 individuals and described that this change was hardly noticed in people before 20 years of age. After 20 years of age, its incidence gradually increased up to sixty years of age as ages advance, however, thereafter the incidence was noticed to be definite. The occurrence incidence in the third decade was $13.5 \%$, in the sixth decade $52.0 \%$, while it rather decreased in the individuals after 60 years of age, the incidence being between 31 and $32 \%$.

In comparing the occurrence incidence of this ruby spot in the Japanese with that in the European people, it was noticed that, this condition in the Japanese is lesser seen than in the European people. However, according to our investigation, it was proved that both people showed the same incidence in the occurrence of this disorder. Further, our observations made known that these ruby spots were already noticed rather frequently in the lateteen agers, and appeared in almost half of the individuals of the fourth decade. As ages advance the incidence increased. On the other hand, it was also 
revealed that its frequency decreased after 71 years of age.

How should this trend in the appearance of ruby spots which is only noticed in the Japanese be then explained? Kodama also noticed that the incidence of this condition in Japanese males decreased after the sixth decade, and further Kojima observed that the proportion of people showing this disorder decreased after 60 years of age. We simply considered that this trend, which is only noticed in the Japanese and not in the European people, is due to the short average life span of the Japanese, and in recent days, as the average life span of the Japanese has neared the line of seventy years, the proportion showing this ruby spot might, as a matter of course, gradually increase even after sixty years of age, as noticed in the European people. Further shouldn't this belief be confirmed in observing that even a good number of aged people showed only one spot?

According to our investigation no significant difference was noticed in the appearance of this condition in both sexes, which same trend was also reported by Raff, Murison et al, Kojima and others. Concerning the distribution of this ruby spot, it has been known for a long time since Jadassohn's description that it is predominantly noticed on the breast and the back. It may appear on the abdomen, further on the extremities and face. Murison made his report only examining the spot on the area of skin extended from the nipple line to the pubis, and laterally as far as the mid-axillary lines, for convenience and from the reason that it is much the commonest site of the spots. We made an attempt to confirm this observation examining the entire area of the skin, and it was concluded that statistic significantly ruby spots were most frequently observed on the breast, next the back and third the abdomen, which conclusion endorsed this Jadassohn's an others' observation.

De Morgan had the belief that the ruby spots may indicate or presage malignant disease, particularly of the stomach. Handley drew attention to the common belief that the spots occur more often in patients affected with cancer, and Murison et al attempted to make clear if there is any influence of disease on incidence of spots, and concluded that De Morgan's spots were slightly commoner in malignant than in non-malignant disease, but not suffciently so to be of diagnostic importance. Although we did not investigate the occurrence of ruby spots specifically in patients having malignant disease, our observation in patients without malignant disease and mostly with common skin disease, and in healthy individuals as stated previously revealed that the occurrence incidence of this spot was as frequent as in Murison et al's report, which made us consider that this condition is not at all related to any malig- 
nant disease, but a condition simply due largely to age. Additionally, isn't this belief especially approved when noticing that this spot is seen rather frequently in even the healthy late-teen agers?

\section{SUMMARY}

Angioma senile was statistically observed in a total of 1802 people, of which 1552 were males and 250 females. The results obtained were as follows:

It is one of the skin changes which are due largely to age, its occurrence incidence gradually increasing as ages advance. Its occurrence is already seen rather frequently in the late teen-agers, the incidence in this group being $\frac{14.09 \%}{17.45 \% \sim 11.43 \%}$ (Occurrence incidence/Confidence limit: Upper limit Lower limit), and it is especially noticed after 40 years of age, the incidence after 40 years being $\frac{68.91 \%}{73.63 \% \sim 66.49 \%}$ in male, and $\frac{64.43 \%}{70.02 \% \sim 59.56 \%}$ in female. The spots increase in number, after the fourth decade the majority showing two or more spots.

No difference was found in sex incidence.

It is most frequently noticed on the breast, next the back, and third the abdomen. Also, it is occasionally seen on the upper arm and the thigh. It may also appear on the neck and nape, face, head. However, it is rarely noticed on the leg and lips. In adolescence it is mostly seen on the breast and the back, and as ages advance it is likely to appear on the abdomen.

We would like to acknowledge indebtedness and express gratitude to Dr. Yokoyama, Professor of Dermatology, School of Medicine, Keio University for assisting and encouraging us during the course of this study. We also desire to acknowledge the courtesy of Instructor Dr. Sato, School of Medicine, Keio University for his painstaking aid and helpful suggestion.

\section{REFERENCES}

1. Jadassohn, J.: Lehrbuch d. Greisenkrh. (Schwalbe, J.), p. 763, 1909.

2. Kodama, H.: Acta Dermatologica (Hifuka Kiyo) 39: 83, 1942 (in Japanese).

3. Kojima, R.: Jap. J. of Dermat. \& Urol. 55, 167, 1944 (in Japanese).

4. Murison, A. R., Sutherland, J. W. \& Williamson, A. M.: Brit. Med. J. 4505: $634,1947$. 